\title{
Bilingualism in the development of phonological awareness skills: an integrative literature review
}

\author{
Ana Carolina Dantas de Medeiros ${ }^{1}$ \\ https://orcid.org/0000-0002-3769-1381 \\ Monalysse Francisca Pereira dos Santos ${ }^{2}$ \\ https://orcid.org/0000-0003-1547-5431 \\ Fernanda Vanessa da Costa Varela ${ }^{2}$ \\ https://orcid.org/0000-0001-8590-5586 \\ Thayane Amanda de Lima Rocha ${ }^{3}$ \\ https://orcid.org/0000-0001-9442-3503 \\ Bárbara Louise Costa Messias ${ }^{4}$ \\ https://orcid.org/0000-0003-4780-8632 \\ Cíntia Alves Salgado Azoni ${ }^{5}$ \\ https://orcid.org/0000-0003-2175-9676
}

Universidade Federal do Rio Grande do Norte - UFRN; Universidade Federal da Paraíba - UFPB, Programa Associado de Pós-graduação em Fonoaudiologia UFPB/UFRN, Natal, Rio Grande do Norte, Brasil.

Centro de Educação e Pesquisa em Saúde Anita Garibaldi - CEPS, Programa de Residência Multiprofissional no Cuidado à Saúde da Pessoa com Deficiência, Macaíba, Rio Grande do Norte, Brasil.

Universidade Federal do Rio Grande do Norte - UFRN, Laboratório de Linguagem Escrita, Interdisciplinaridade e Aprendizagem - LEIA, Natal, Rio Grande do Norte, Brasil.

Universidade Federal do Rio Grande do Norte - UFRN, Natal, Rio Grande do Norte, Brasil.

Universidade Federal do Rio Grande do Norte - UFRN, Departamento de Fonoaudiologia; Programas de Pós-graduação em Fonoaudiologia e Psicologia, Natal, Rio Grande do Norte, Brasil.

Research support source: National Council for Scientific and Technological Development - CNPq.

Conflict of interests: Nonexistent

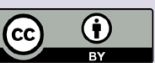

Received on: March 22, 2020

Accepted on: July 15, 2020

Corresponding address:

Cíntia Alves Salgado Azoni

Rua General Gustavo Cordeiro de Farias, $\mathrm{s} / \mathrm{n}-$ Petrópolis

CEP:59012-570 - Natal, Rio Grande do Norte, Brasil

E-mail: cintiasalgadoazoni@gmail.com

\section{ABSTRACT}

Purpose: to verify the influence of bilingualism on the development of phonological awareness.

Methods: this is an integrative literature review, built on the hypothesis of the relationship between bilingualism and its influence on the development of phonological skills in children. The construction was carried out in the databases: CAPES, Pubmed, Scielo, Eric, and LILACS, using the following free terms in Portuguese and English: bilingualism AND phonology, bilingualism AND phonological awareness and bilingualism AND phonological skills. The sample selection criteria were: a) scientific papers published in national and international journals with full text, free and available in the database; b) in English and Portuguese; c) that addressed the theme in the last five years. For the selection of the papers, reading the title, followed by the summary, and finally, reading the papers potentially relevant for review were considered.

Results: following the eligibility criteria, 2,578 papers were identified. Of these, 87 were selected for complete analysis. The final sample consisted of eight papers, two of them being written by Brazilian authors. Of these, five showed better phonological awareness skills in bilinguals and two in monolinguals. Studies point out that age can be a predictor of language skills and better phonological awareness skills associated with good reading development. Bilinguals, early exposed to this skill, develop reading by phonology and those with late exposition, by semantics.

Conclusion: the present study demonstrated that there are still controversies regarding the impacts of bilingualism on phonological awareness, including on the benefits of phonological awareness.

Keywords: Bilingualism; Language; Child Development; Education; Child 


\section{INTRODUCTION}

The globalization process brought to society children increasingly exposed to other languages at an early age. As a result, the demand for schools offering bilingual education has increased in Brazil in recent decades ${ }^{1}$.

The child's native language learning happens through interaction with family members. The acquisition of a new language can positively influence language skills, which are essential in developing a good reader ${ }^{2}$. Still, the proper development of the first language favors and facilitates the acquisition of a new language, influenced by psycholinguistic predictors that involve, among others, the syntactic, phonological, and lexical levels ${ }^{3}$.

Teaching is considered bilingual when the child is exposed to at least two different languages since it is essential to interact with the world around them through experience so that they assume communication roles with other interlocutors ${ }^{4}$.

The acquisition of the second language can occur in two ways: the first called simultaneous, in which the child is exposed to two languages at an early age, usually occurs in families with parents of different nationalities; and the second, sequential acquisition, the child first learns the native language and, when entering school, is inserted in another language ${ }^{5}$.

The individual is considered bilingual when he speaks two different languages fluently, which is the most well-known and accepted theory. However, the concept of bilingualism is still discussed by researchers, as there is no consensus since questions arise regarding the equivalence of the levels of oral and reading comprehension, fluency, and writing, in both languages that do not always manifest themselves in a balanced way ${ }^{6}$. In Brazil, there is great interest and concern from parents in offering children the opportunity to learn a new language ${ }^{7}$.

Among metalinguistic skills, phonological awareness stands out for contributing to the literacy phase and involves the ability to reflect explicitly on the structure of the word, understanding it as a sequence of syllables and/or phonemes. This skill is related to the development of written language since alphabetical reading associates the auditory component (phoneme) with a visual graphic component (grapheme), called grapheme-phoneme correspondence ${ }^{8}$. Thus, it is believed that the moment of insertion of children in bilingual education in the period of literacy can have positive interferences in metalinguistic skills that are directly related to learning to read ${ }^{9}$.

Despite this, researchers seek to investigate bilingualism from the perspective of language and its development. It is believed that children who learn a new language have benefits in higher functions in the acquisition of their native languages, such as attention, memory, imagination, inhibition, programming, planning, and the language itself ${ }^{10}$.

Much of the advantages observed in bilingualism in terms of phonological awareness were based on the Theory of Transferences between Languages ${ }^{11}$. The two phonological systems found in bilingual children perform interlinguistic interactions with each other that could yield positive effects, such as the acceleration that is related to the early acquisition of a phonological structure, established in comparison to those of a monolingual child; or negative effects, called deceleration, when there is a delay in the phonological development of bilinguals compared to monolinguals, often conceptualized as delay in acquisition ${ }^{12}$.

In the face of positive linguistic transfer, bilingual children can learn earlier some phonological aspects than monolingual ones. Some measures should be considered when evaluating bilingual children, such as the age of acquisition of each language and the relative amount of experience or exposure, as they can be responsible for a large part of phonological skills variations ${ }^{13}$.

In this way, there may be an advantage for bilingual individuals in terms of phonological awareness when they are exposed to an alphabetical writing system, or when the native language has a simpler and more regular phonological structure ${ }^{11-14}$.

Thus, the need arose to verify in the literature, studies from the last few years to understand how much bilingualism has a beneficial influence or not on the development of phonological awareness, given the growing demand for bilingual children in Brazilian schools who may or may not have difficulties in the development of language skills $s^{3,13,14}$.

Hence, the present study sought to clarify the possible effects caused in the development of phonological awareness by the simultaneous or sequential acquisition of a new language in early childhood.

Therefore, in order to verify the influence of bilingualism on the development of phonological awareness, the guiding question for this study was: "Do bilingual children have a better development in phonological awareness skills than monolingual ones?" 


\section{METHODS}

This study is an integrative literature review, built on the hypothesis of the relationship between bilingualism and its influence on the development of phonological awareness skills in children.

This integrative review involved the following steps: preparation of the guiding question, the establishment of keywords and eligibility criteria, selection of papers, and critical evaluation of them.

The construction of this study was carried out through a national and international bibliographic survey indexed in the databases: CAPES, Pubmed, Scielo, Eric and LILACS journals, on the subject in evidence, using the following free terms in Portuguese: "bilinguismo AND consciência fonológica", "bilinguismo AND habilidades fonológicas", "bilinguismo AND fonologia". And in English: bilingualism AND phonology, bilingualism AND phonological awareness and bilingualism AND phonological skills.

The eligibility criteria for selecting the sample were: a) papers published in national and international journals with full text, free and available in the database; b) in English and Portuguese; c) to address the theme in the last five years.

For the selection of papers, two independent evaluators considered reading by the title, followed by reading the abstract and, finally, reading papers potentially relevant for the review. Duplicate papers were excluded and in case of divergence between the reviewers, a third reviewer was requested.

The analysis was performed using a Microsoft Excel spreadsheet, with the tabulation of the following data: year, identification of the authors, database, periodical, impact factor, the country where the study was carried out, objective, sample, type of study, phonological awareness assessment methods, main results, and conclusion.

In the databases Eric, Scielo, Pubmed and Lilacs, there was no result of papers for the descriptors in Portuguese, so when searched in English at Eric, papers were found before and after applying the filter, respectively: 483 papers and 3 , for the term "bilingualism AND phonology"; 139 and 13, for the term "bilingualism AND phonological awareness"; 150 and 3 , for the term "bilingualism AND phonological skills"; totaling 19 papers. For Scielo, only 2 results were obtained for the term "bilingualism AND phonology". At Lilacs, for the term "bilingualism AND phonology" 1 paper was found before the filter, for "bilingualism AND phonological awareness" and "bilingualism AND phonological skills", 1 paper was found for each term even with the filter, totaling 2. For Pubmed, 117 papers were found before and after the filter was applied, remained 23, for the term "bilingualism AND phonology"; 71 and 12, for the term "bilingualism AND phonological awareness"; 81 and 13, for the term "bilingualism AND phonological skills"; totalizing 48 papers for this database. The Capes Periodical found 4,873 unfiltered papers, 912 filtered papers with the term "bilingualism AND phonology", 2,814 and 666 papers with "bilingualism and phonological awareness", and 3,585 and 929 papers with "bilingualism and phonological skills", obtaining a total of 2,507 papers. 
Database and number of papers identified

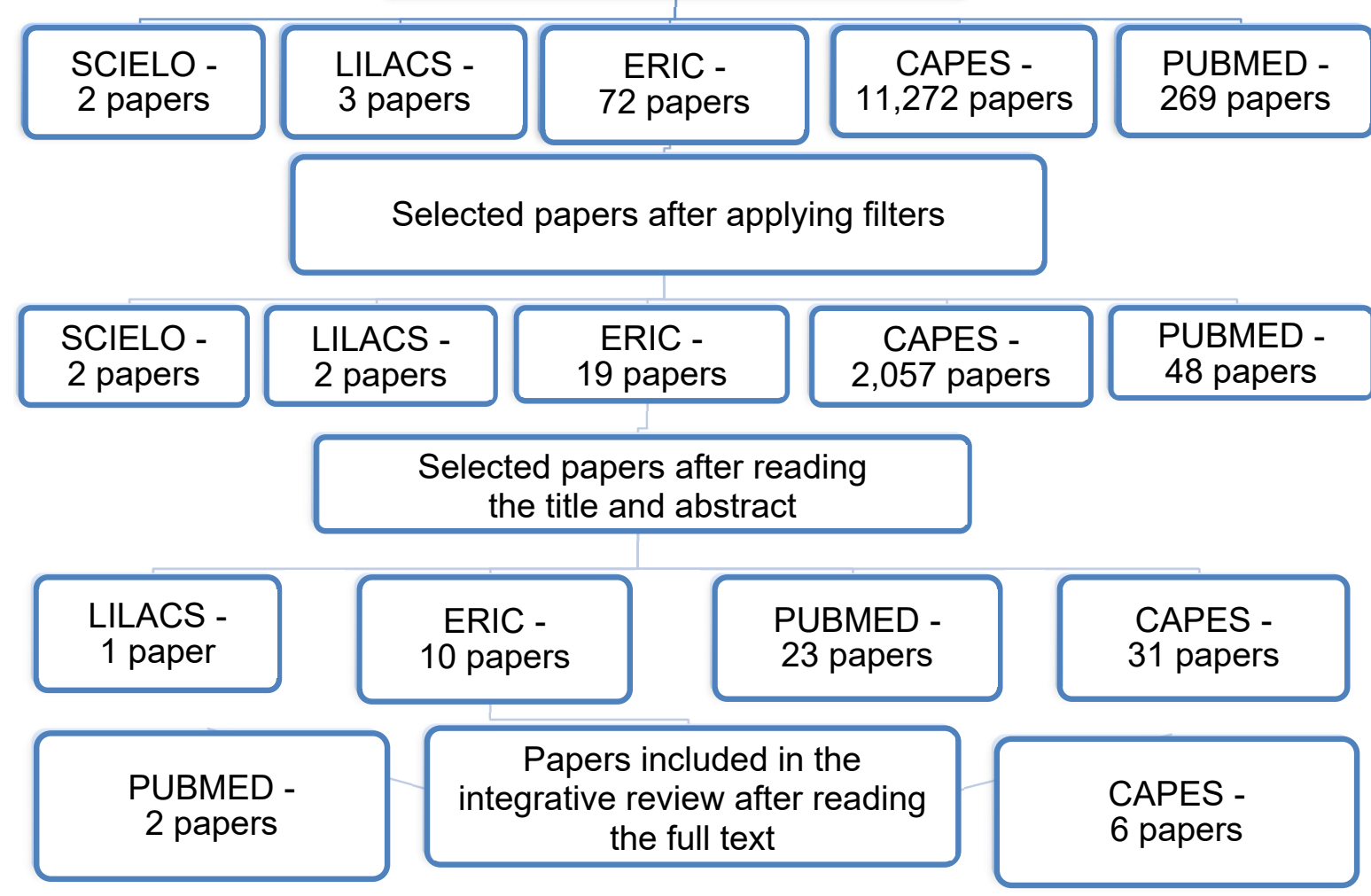

Figure 1. Flowchart of paper selection

\section{LITERATURE REVIEW}

In the selected databases, 12,318 papers were found. Following the eligibility criteria, 2,578 papers were selected. Of these, 87 papers were selected for full reading, with the final sample consisting of 6 papers in an international journal and 2 national papers, totaling 8 papers.

Five papers indicated a better mastery of phonological awareness tasks $\mathbf{s}^{8,10,15-17}$ for bilingual children and two for monolingual children. The following phonological awareness tasks were evaluated: phonemic awareness, rhyme. Phonological processing skills (memory, phonological awareness, and access to the mental lexicon) ${ }^{14}$ and executive attention ${ }^{17}$ were also assessed.

Regarding the countries and languages studied, two took place in Brazil, one in the United Kingdom, two in Singapore, one in Portugal, one in Germany and one in Canada.

As for bilinguals, the languages exposed were: Brazilian Portuguese - English, Polish - English, Portuguese from Portugal - English / German / Brazilian Portuguese and Venezuelan Spanish, English - French, English - Chinese, Turkish - German, Chinese - English.
The bilinguals presented better performances of phonological skills at the phonemic level and the monolingual group in the tasks of rhyme, alliteration, and syllabic segmentation ${ }^{18}$. However, another study showed better results in the bilingual group in the tests for phoneme identification, exclusion of final phoneme, and sound categorization ${ }^{16}$. Likewise, a paper showed similarity in the assessed phonological awareness skills ${ }^{19}$.

Furthermore, the predictive skills of phonological awareness of bilinguals can be bidirectional to the functioning of executive attention, being more accentuated in the alliteration of English and the perception of Chinese rhyme ${ }^{17}$.

Studies indicate that age can be a predictor of language skills and better phonological awareness skills associated with good reading development. Bilinguals exposed to early reading develop reading by phonology and those exposed late by the support of semantics ${ }^{10}$. Another study identified that bilingual children depended more on vocabulary skills, while monolingual readers used more phonological awareness skills to understand reading ${ }^{16}$. 


\begin{tabular}{|c|c|c|c|c|}
\hline Identification & Parents & Goals & Methodologies & Results \\
\hline $\begin{array}{l}\text { Profile of phonological } \\
\text { awareness in bilingual and } \\
\text { monolingual children }\end{array}$ & Brazil & $\begin{array}{l}\text { Compare the performance of } \\
\text { phonological awareness skills } \\
\text { of bilingual and monolingual } \\
\text { students of both genders. }\end{array}$ & $\begin{array}{l}\text { Observational, cross-sectional, } \\
\text { and descriptive. } 17 \text { third-year } \\
\text { students, aged between seven and } \\
\text { eight years and } 11 \text { months. }\end{array}$ & $\begin{array}{l}\text { There was a difference in performance in } \\
\text { phonological awareness skills, greater domain } \\
\text { of bilingual children in phonemic awareness. } \\
\text { Bilingual boys showed better performance than } \\
\text { their monolingual peers, while bilingual girls } \\
\text { did not reveal important differences. }\end{array}$ \\
\hline $\begin{array}{l}\text { Age of Bilingual Exposure Is } \\
\text { Related to the Contribution of } \\
\text { Phonological and Semantic } \\
\text { Knowledge to Successful } \\
\text { Reading Development }{ }^{10}\end{array}$ & Canada & $\begin{array}{l}\text { Understand how bilingual } \\
\quad \text { experiences impact } \\
\text { phonological awareness and } \\
\text { semantic knowledge and, in } \\
\text { turn, impact reading results } \\
\end{array}$ & $\begin{array}{l}\text { Control case. } 421 \text { children from } \\
\text { grades } 1 \text { to } 4 \text { participated in the } \\
\text { study between } 2009 \text { and } 2011 .\end{array}$ & $\begin{array}{l}\text { Bilingual children showed an advantage in } \\
\text { phonological awareness skills, which was } \\
\text { associated with early bilingual exposure. }\end{array}$ \\
\hline $\begin{array}{l}\text { How Does L1 and L2 Exposure } \\
\text { Impact L1 Performance in } \\
\text { Bilingual Children? Evidence } \\
\text { from Polish-English Migrants to } \\
\text { the United Kingdom }{ }^{14}\end{array}$ & $\begin{array}{l}\text { United } \\
\text { Kingdom }\end{array}$ & $\begin{array}{l}\text { Investigate patterns of native } \\
\text { language development in } \\
\text { migrant children raised } \\
\text { bilingual. }\end{array}$ & $\begin{array}{l}\text { Cross-sectional, descriptive, } \\
\text { and observational. } 223 \text { Polish } \\
\text { and English immigrant children } \\
\text { residing in the UK from four to } \\
\text { seven years old ( } 88 \text { bilingual and } \\
145 \text { monolingual) }\end{array}$ & $\begin{array}{l}\text { In the phonological processing task, } \\
\text { the bilingual group scored less than the } \\
\text { monolingual group. }\end{array}$ \\
\hline $\begin{array}{l}\text { A comparative study on } \\
\text { phonological acquisition and } \\
\text { performance in phonological } \\
\text { awareness by children exposed } \\
\text { to a bilingual or monolingual } \\
\text { family environment }{ }^{15}\end{array}$ & Brazil & $\begin{array}{c}\text { To verify and compare } \\
\text { phonological acquisition and } \\
\text { performance in phonological } \\
\text { awareness tasks among } \\
\text { children exposed to a } \\
\text { bilingual family environment } \\
\text { (Brazilian Portuguese and } \\
\text { German) and children } \\
\text { exposed to a monolingual } \\
\text { family environment (Brazilian } \\
\text { Portuguese) } \\
\end{array}$ & $\begin{array}{l}\text { Cross-sectional, exploratory, and } \\
\text { quantitative. It was carried out } \\
\text { with } 32 \text { children of both sexes, } \\
\text { aged five years, divided into the } \\
\text { bilingual group (13 children - } \\
\text { Portuguese and German) and the } \\
\text { monolingual group (19 children } \\
\text { - Portuguese). }\end{array}$ & $\begin{array}{l}\text { Children exposed to the bilingual environment } \\
\text { had better results only in the task of phonemic } \\
\text { synthesis. In other tasks of phonological } \\
\text { awareness, children exposed to the } \\
\text { monolingual environment obtained better } \\
\text { results. }\end{array}$ \\
\hline $\begin{array}{c}\text { Promoting phonological } \\
\text { awareness in pre-primary } \\
\text { education: possibilities of } \\
\text { the awakening to languages } \\
\text { approach }^{16} \\
\end{array}$ & Portugal & $\begin{array}{l}\text { Evaluate and understand } \\
\text { the effects of awakening for } \\
\text { the language program with } \\
\text { children on the development of } \\
\text { phonological awareness. } \\
\end{array}$ & $\begin{array}{l}\text { Mixed search method. } 21 \\
\text { Portuguese children aged three to } \\
\text { six years were evaluated. }\end{array}$ & $\begin{array}{c}\text { Bilinguals had better results in phonological } \\
\text { awareness with the development of } \\
\text { phonological skills when compared to } \\
\text { monolinguals. }\end{array}$ \\
\hline $\begin{array}{l}\text { The relationship between } \\
\text { phonological awareness and } \\
\text { executive attention in Chinese- } \\
\text { English bilingual children }{ }^{17}\end{array}$ & Singapore & $\begin{array}{l}\text { Examine the relationship } \\
\text { between phonological } \\
\text { awareness and executive } \\
\text { attention among bilingual } \\
\text { Chinese and English children in } \\
\text { the process of learning to read. } \\
\end{array}$ & $\begin{array}{l}\text { Cross-sectional, observational, } \\
\text { and descriptive. Performed with } \\
74 \text { bilingual children (English- } \\
\text { Chinese) }\end{array}$ & $\begin{array}{l}\text { Bilinguals performed better than expected } \\
\text { for all phonological awareness skills, except } \\
\text { alliteration in Chinese. }\end{array}$ \\
\hline $\begin{array}{l}\text { Differential Growth Patterns } \\
\text { in Emerging Reading Skills of } \\
\text { Turkish-German Bilingual and } \\
\text { German Monolingual Primary } \\
\text { School Students }{ }^{18}\end{array}$ & Germany & $\begin{array}{c}\text { Examine whether there are } \\
\text { different growth patterns } \\
\text { between basic reading skills } \\
\text { among students of Turkish- } \\
\text { German bilinguals and German } \\
\text { monolinguals. } \\
\end{array}$ & $\begin{array}{l}\text { Control, longitudinal, and } \\
\text { observational case. } 100 \text { Turkish- } \\
\text { German bilingual children and } 69 \\
\text { monolingual German monolingual } \\
\text { children from the first to the third } \\
\text { year were evaluated. }\end{array}$ & $\begin{array}{l}\text { An advantage in phonological awareness } \\
\text { for bilingual children at the beginning of the } \\
\text { second year. }\end{array}$ \\
\hline $\begin{array}{l}\text { Metalinguistic contribution to } \\
\text { writing competence: a study } \\
\text { of monolingual children in } \\
\text { China and bilingual children in } \\
\text { Singapore }\end{array}$ & $\begin{array}{l}\text { Singapore / } \\
\text { China }\end{array}$ & $\begin{array}{l}\text { To investigate the simultaneous } \\
\text { contributions of three } \\
\text { components of metalinguistic } \\
\text { awareness (phonological, } \\
\text { morphological, and syntactic } \\
\text { awareness) in the writing } \\
\text { of primary English-Chinese } \\
\text { bilingual children in Singapore } \\
\text { and Chinese-speaking } \\
\text { monolingual children. }\end{array}$ & $\begin{array}{l}\text { Control, transversal, and } \\
\text { observational case. } 390 \text { bilingual } \\
\text { children ( } 181 \text { girls and } 209 \text { boys) } \\
\text { and } 190 \text { monolingual children ( } 92 \\
\text { girls and } 98 \text { boys) were evaluated }\end{array}$ & $\begin{array}{l}\text { Bilingual children obtained results similar } \\
\text { to monolingual children in the phonological } \\
\text { awareness test. }\end{array}$ \\
\hline
\end{tabular}

Figure 2. Summary of papers selected for the integrative review 
This review aims to verify whether bilingual children have a better command of phonological awareness than monolingual ones. The findings show that bilingualism has an important influence on performance in phonological awareness tasks.

The authors sought to compare performance in different contexts, such as the bilingual family environment ${ }^{10,18}$ and sequential exposure ${ }^{8}$.

The child inserted in a second language may have better metacognitive skills in linguistic planning, monitoring, and control. Besides, the interference of higher functions acquired in the acquisition of the native language, such as attention, memory, language, imagination, inhibition, programming, and planning. This framework can provide a better mastery of reading and writing skills in the native language ${ }^{11}$.

Research with bilingual individuals has shown advantages in phonological processing, which is not limited to phonological awareness ${ }^{4}$. However, this ability can be reduced in bilingual children when compared to monolinguals, which may be associated with language transparency ${ }^{14}$.

Thus, it was possible to observe that most studies reported the advantage of bilingual individuals in terms of phonological awareness $8,10,15-17$. This finding is related to a better experience in a new language due to the native language having a simpler or regular phonological structure, or to the alphabetical writing system ${ }^{4}$.

In a study with monolingual and bilingual children, in the third school year, aged between 7 and 8 years old, it was found as a result of a better performance of bilinguals in the ability of sequential rhyme and in the final result of the test used to assess the phonological awareness ${ }^{8}$.

Another study observed that investing in the stimulation of minimal and contrasting differences between phoneme pairs collaborates in stimulating the phonological awareness ability and, consequently, reflects in the reading of words from L1 and later in L2. Thus, lexical specificity training influenced the awareness of phonemes in English, is considered a predictor of early reading skills in both languages, English and French. English stood out as the strongest language, with the best indicator of total phonological awareness. Children who scored higher in the lexical specificity task in English also had significantly better phonological awareness in this language and those with higher scores in English phonological awareness showed better performance in reading French words ${ }^{20}$.
Furthermore, two studies found that monolingual teaching can have advantages in phonological processing skills (phonological awareness, phonological working memory, and access to the mental lexicon), especially in phonological awareness ${ }^{14,15}$.

Although most studies have found benefits from bilingualism in the development of phonological awareness, a Dutch study with children exposed to monolingual (Dutch), advanced sequential bilingual (Dutch-English), and simultaneous bilingual (DutchEnglish), found that the effects phonological awareness did not show significant statistical differences ${ }^{21}$.

In this way, the two phonological systems found in bilingual children, perform interlinguistic interactions between themselves positive or negative12. In the face of positive language transfer, bilingual children can learn some phonological aspects earlier than monolingual ones. Some measures should be considered when evaluating bilingual children, such as the age of acquisition of each language and the relative amount of experience or exposure, as they can be responsible for a large part of variations in phonological skills. Thus, children's early exposure to a second language may present better phonological awareness performances when compared to those exposed late ${ }^{10}$.

Much of the advantages observed in bilingualism regarding phonological awareness were based on the Cross-Language Transfer Theory. in which speakers apply the knowledge of their native language in the new language, which can generate positive effects in the second language ${ }^{4}$.

In the relationship between monolingual and bilingual teaching with the performance analyzed by sex, bilingual males were highlighted in the ability to add phonemes ${ }^{8}$. What differs from another study that brings the male gender as a variable linked to worse language development, along with the mother's educational level, family, and health history since the gestational period ${ }^{22}$.

The relevance of this study may guide field research regarding the understanding of the development and performance in phonological awareness in bilingual children in the educational context, with a greater understanding of possible difficulties presented in this group.

\section{CONCLUSION}

The present study demonstrated that there are still controversies regarding the impacts of bilingualism on phonological awareness since two studies did not 
show better performance of bilinguals. However, in six studies, bilingual children performed better than monolinguals in specific tasks of this skill. This may be related to early exposure to two languages.

Studies have shown that bilingual boys perform better in phonological awareness when compared to monolingual ones, while the same was not found for girls, with a similar performance for both bilinguals and monolinguals.

This integrative review allowed to reinforce the hypothesis that the development of phonological awareness can be positively influenced by the learning of another language.

\section{ACKNOWLEDGMENT}

This work was carried out with the support of the Coordination for the Improvement of Higher Education Personnel - Brazil (CAPES), financing code 001 ".

\section{REFERENCES}

1. Fávaro FM. A educação infantil bilíngue (português/inglês) na cidade de São Paulo e a formação dos profissionais da área: um estudo de caso [Dissertação]. São Paulo (SP): Pontifícia Universidade Católica de São Paulo, Curso de Mestrado em Linguística Aplicada e Estudos da Linguagem; 2009.

2. Kuo LJ, Uchikoshi Y, Kim TJ, Yang X. Bilingualism and phonological awareness: re-examining theories of cross-language transfer and structural sensitivity. Contemporary Educational Psychology. 2016;46(1):1-9.

3. Megale $\mathrm{AH}$. Bilinguismo e educação bilíngue discutindo conceitos. ReVEL. 2005;3(5):1-13.

4. Butler YG, Hakuta K. Bingualism and second language aquisition. In: Bhatra JK, Ritchie WC (orgs). The handbook of binliguism. Oxford: Clackwell Publishing, 2006. p.114-37.

5. Flores BTM. Bilinguismo. Textura. 2005;7(12):79-89.

6. Kipper E. Aquisição de segunda língua em contextos de bilinguismo societal. Letrônica. 2012;5(3):88-102.

7. Souza LBR, Leite AGC. Profile of phonological awareness in bilingual and monolingual children. CoDAS. 2014;26(1):61-7.

8. Guimarães SRK, Paula FV. O papel da consciência morfossintática na aquisição e no aperfeiçoamento da leitura e da escrita. Educ. rev. 2010;(38):92-111.
9. Jasińska KK, Petitto LA. Age of bilingual exposure is related to the contribution of phonological and semantic knowledge to successful reading development. Child Dev. 2018;89(1):310-31 .

10. Hickmann G, Guimarães S, Hickmann A. Aprendizado bilíngue e linguagem escrita: desenvolvimento de habilidades metalinguísticas. Cad. Pes. 2017;24(2):156-69.

11. Core C, Scarpelli C. Phonological development in young bilinguals: clinical implications. Semin Speech Lang. 2015;36(2):100-8.

12. Goulart MTC, Torresi ECB, Silva HS, Parente MAMP. Correlatos neurais de diferentes experiências linguísticas: impactos do analfabetismo e bilinguismo sobre a cognição. Revista Neuropsicologia Latinoamericana. 2017;9(3):28-41.

13. Meir N, Armon-Lotem S. Independent and combined effects of Socioeconomic Status (SES) and bilingualism on children's vocabulary and verbal short-term memory. Frontiers in Psychology. 2017;8(1):1-12.

14. Haman E, Wodniecka Z, Marecka M, Szewczyk J, Białecka-Pikul M, Otwinowska A et al. How Does L1 and L2 exposure impact L1 performance in bilingual children? Evidence from Polish-English migrants to the United Kingdom. Front. Psychol. 2017;8(1):327-45.

15. Lourenço M, Andrade Al. Promoting phonological awareness in pre-primary education: possibilities of the awakening to languages approach. Language Awareness. 2013;23(4):304-18.

16. Limbird CK, Maluch JT, Rjosk C, Stanat P, Merkens $H$. Differential growth patterns in emerging reading skills of Turkish-German bilingual and German monolingual primary school students. Reading and Writing. 2014;27(5):945-68.

17. Yang $\mathrm{H}$, Yang $\mathrm{S}$, Kang $\mathrm{C}$. The relationship between phonological awareness and executive attention in Chinese-English bilingual children. Cognitive development. 2014;30(1):65-80.

18. Brancalioni AR, Bogoni AP, Silva DP, Giacchini V. A comparative study on phonological acquisition and performance in phonological awareness by children exposed to a bilingual or monolingual family environment. Rev. CEFAC. 2018;20(6):703-14.

19. Sun B, Hu G, Curdt-Christiansen XL. Metalinguistic contribution to writing competence: a study of monolingual children in China and bilingual children in Singapore. Reading and Writing. 2018;31(7):1499-523. 
20. Krenca K, Segers E, Chen X, Shakory S, Steele J, Verhoeven L. Phonological specificity relates to phonological awareness and reading ability in English-French bilingual children. Reading and Writing. 2020;33(2):267-91.

21. Goriot C, Unsworth S, Hout RV, Broersma M, McQueen JM. Differences in phonological awareness development: are there positive or negative effects of bilingual experience? Linguistic Approaches to Bilingualism. 2019;9(6):1-34.

22. Moriano-Gutierrez A, Colomer-Revuelta J, Sanjuan $\mathrm{J}$, Carot-Sierra JM. Environmental and genetic variables related with alterations in language acquisition in early childhood. Rev Neurol. 2017;64(1):31-7. 